\title{
PROVA NA TEORIA DOS ATOS ADMINISTRATIVOS
}

\author{
EVIDENCE IN ADMINISTRATIVE ACTS DOCTRINE
}

Florence Cronemberger Haret

\begin{abstract}
Resumo:
Esta matéria versa sobre a reflexão teórica ao tema da prova no Direito Tributário que, atualmente, se percebe grande tendência a se priorizar a prática em detrimento da teoria propriamente dita.

Palavras-chave: Prova no Direito Tributário. Teoria propriamente dita.

Abstract:

This text is a theoretical reflection on evidence in Tax Law that, in the present. on note great tendency to give more priority to practical aspects than theory by itself.
\end{abstract}

Keywords: Evidence in Tax Law. Theory by itself.

\section{Preliminares}

A proposta deste trabalho é uma reflexão teórica sobre o tema da prova no Direito Tributário. Hoje, percebe-se grande tendência a se priorizar a prática em detrimento da teoria. Aqui, proponho justamente o contrário. Postuladas as premissas teóricas, ingressarmos na experiência jurídica conferindo fundamentos científicos à prática, proporcionando explicação embasada num método e num corte epistemológico único.

A Filosofia do Direito não é matéria da Ciência do Direito em sentido estrito;' no entanto, é com apoio indispensável da Filosofia que ingressaremos neste estudo. Adentrando às inovações conceptuais do Constructivismo Lógico Semântico de Lourival Vilanova na Teoria Geral do Direito, posteriormente desenvolvidas por Paulo de Barros Carvalho na área Tributária, tomaremos o sistema jurídico como um sistema comunicacional. Neste viés, direito é texto, direito é linguagem, direito é comunicação.

A linguagem do Direito não coincide, no entanto, com a linguagem natural, usada no dia-a-dia. É uma linguagem específica que prioriza seus objetivos: a regulação de condutas. Para tanto, utiliza-se de conceitos que objetivam abarcar o maior proveito no uso de cada vocábulo, prescrevendo, desta forma, o maior número de condutas possíveis. Com tais características, o direito é uma linguagem técnica.

Pesquisadora da FAPESP e aluna do $5^{\circ}$ ano dos Cursos de Graduação da Faculdade de Direito da Universidade de São Paulo.

1 Também chamada de dogmática do Direito. 
A Ciência do Direito, por sua vez, é descritiva desta linguagem técnica. ou melhor dizendo, é metalinguagem do direito, servindo-se dele como linguagem-objeto. Da mesma forma que o sistema lingüístico normativo, a linguagem científica não coincide com a linguagem natural, por ter uma sintaxe rigorosa, especificando. no plano semântico. o conteúdo que persegue. Ambas as linguagens, técnica, do direito, e científica, da Ciência do Direito, perdem para a pragmática da linguagem natural, visto que $\omega$ uso daquelas é reduzido em detrimento da contingência e da precisão da forma e do conteúdo que thes são inerentes.

O que se percebe, porém, é que em regra toda linguagem é constituída de unidades de sentido: o signo lingüístico. Este pode ser uma palavra, uma frase, uma oração. Desde que tenha um suporte físico, associado a uma significação e um significado, este conjunto lógico-relacional passa a ser signo, a ser objeto de compreensão. O suporte físico, como o próprio nome já o diz, confere ao signo a natureza física. É a maneira que se encontrou na comunicação para divulgar a mensagem. No entanto, só há mensagem quando se tiver uma idéia, uma noção. É justamente com a adição do "significado" c da "significação" que teremos a noção do signo lingüístico.

No Direito, dentro da concepção lógico-construtivista, a norma jurídica é tida como o signo lingüístico, visto que é ela o suporte portador do sentido a ser compreendido pelo exegeta da linguagem do direito. É na norma jurídica que encontraremos a mensagem legislada. de um lado, e o sistema normativo, de outro, posto que norma nenhuma é criada sem a sua submissão aos ditames formais e semânticos do direito positivado. Nas palavras de Lourival Vilanova, "a norma juridica é uma estrutura lógico-sintática de significação, que conceitua fatos e condutas representando-os como significações objetivas. A proposição normativa (juridica ou prescritiva) é sua forma lógica, revelando estrutura hipotética geral ou individual, abstrata ou concreta" " São, neste sentido. juízos prescribentes, criados pela mente de um sujeito legalmente competente. que, verbalizados. tomam a forma de uma frase jurídica.

Destas preliminares, tiramos duas premissas deste estudo: (i) o Direito Positivo é uma linguagem técnica, ordenado na forma de sistema comunicacional; e (ii) a norma jurídica compõe este sistema como unidade sígnica.

Por outro lado, o ordenamento jurídico caracteriza-se por ser uma ordem cultural. O foco de sua ontologia são os objetos culturais que se encontram permeados na

VILANOVA, Lourival. Norma juridica · proposição jurídica. Revisıa de Direilo Público, São Paulo, n. 61, p. 17. 1982. 
vida em sociedade. O objeto de conhecimento do Direito Positivo, em sentido amplo, são aqueles eventos factuais escolhidos pelo legislador e determinados em lei, que tem a potencialidade de refletirem os valores daquela sociedade. Em sentido estrito, por sua vez, não se referem aos objetos reais, os eventos, que estarão sempre fora do sistema jurídico, pois intangíveis pela linguagem. mas tão somente aqueles objetos interiores, criados e compreendidos pela consciência do homem a partir do estímulo da percepção do objeto real.

Estamos falando. portanto, de ontologias diferentes: (i) o objeto real. aquele percebido pelo ser cognoscente e manifestado num tempo e num espaço determinado. que. quando comunicado, será sempre uma transformação do real e permanecerá íntegro somente no passado; (ii) e aquele, objeto cultural, compreendido pelo exegeta do Direito, sob a égide do sistema interpretativo do direito posto. O objeto do ordenamento jurídico é. portanto, o conteúdo de uma forma de consciência.

A digressão foi longa mas oportuna para avançar algumas concepções sobre o estudo da prova ora proposto. Viu-se que o Direitu não toca a realidade, pois. como linguagem, retrata sempre parte do real. Deste, surge um novo objeto. signo lingüístico. já inserido na estrutura do sistema jurídico. Neste sentido, a linguagem do Direito cria sua própria realidade, transformando lingüisticamente os objetos reais. As proposiçôes jurídicas são, portanto. instituidoras do que "assim deve ser" a realidade jurídica: enquanto que. nos fatos naturais, as proposições nada criam, pois "assim é" havendo ou não linguagem.

Concluímos, portanto, que as proposições são a forma de concreção existencial do Direito Pusitivo. De um lado, elas fazem referência objetiva aos eventos factuais, suporte físico da significação da proposição, e, de outro lado, requerem a frase, ou seja, a forma gramatical de propusição jurídica. São estes os dois vieses da concreção do urdenamento positivado. E é neste panorama que a análise do instituto da prova se integra.

Estudar a prova na dinâmica da incidência normativa dista de ser fácil. Ao mesmo tempo, é ela o próprio retrato da gramaticabilidade da comunicação normativa (redução lógico-formal do ordenamento positivo), e é também o mecanismo competente para a construção dos fatos jurídicos. Em outras palavras, é a técnica escolhida pelo direito positivo para desencadear a articulação normativa que, huscando seu fundamento de validade no topo da pirâmide do Direito, na norma geral e abstrata, constitui-se em um instrumental poderoso para qualificar os enunciados fácticos, determinando a estrutura de uma nova norma, agora norma individual e concreta. Daqui, verificam-se já 
dois momentos diversos de análise: (i) no âmbito da norma geral e abstrata e (ii) na expedição da norma individual e concreta.

Eis que numa tentativa introdutória de determinar o instituto da prova. já nos deparamos com conceitos complexos e com uma diversidade infindável de acepções a ela empregadas. Dentro desta primeira apresentação do estudo ora proposto, poderemos entendê-la quer como o "fato concreto" ("fato gerador"), quer como a norma individual e concreta, quer mesmo como técnica jurídica processual ou como a própria incidência normativa, ou ainda como o próprio fundamento de validade da norma. Enfim, são inúmeras as possibilidades semânticas. Breves investigações semânticas, como a que acabamos de fazer, revelam que o tema pede desenvolvimento.

\section{A teoria da prova sob análise semiótica}

O presente trabalho busca estudar as provas, sob novos parâmetros epistemológicos. Com o apoio da filosofia e das evoluções cognoscitivas impulsionadas pelo Circulo de Viena e pelo movimento do giro-linguístico, foi possível verificar na prova novos traços científicos, garantindo, ao mesmo tempo, a seriedade e a firmeza das premissas eleitas ao longo do trabalho.

O modelo com o qual se opera neste estudo foi, justamente, a idéia do Direito como expressão da comunicação humana. Neste sentido, a realidade juridica é uma construção lingüistica em que se busca regular condutas. O Direito usa a linguagem como forma de direcionar os utentes deste sistema a seus determinados valores. Logo, o ordenamento é, por excelência, a própria expressão axiológica da sociedade a ele imersa. Os signos jurídicos serão observados como o discurso artificialmente construído para relatar com precisão a realidade objetiva do direito, expressão dos objetos culturais, que só poderão ser compreendidos, na medida, em que os utentes desta realidade estejam diante de um mesmo código sistemático de comunicação - o Direito Positivo.

Alinhados nesta direção epistemológico, o sistema jurídico apresentará formas sígnicas específicas com o objetivo de precisar a mensagem legislada. E é na norma, proposição jurídica que se destina a regular as condutas das pessoas nas relações entre homens, que iremos encontrar o signo lingüístico componente do ordenamento positivado. Ela é a unidade de significação do direito e também expressão do conjunto normativo. Sem o sistema, como um todo, não há norma: sem norma, não há sistema jurídico.

A frase normativa, como fórmula lingüistica, será fechada em termos sintáticos, circunscrita dentro das correlações de coordenação e de subordinação 
sistemáticas impostas pelo direito positivo. Só será norma aquele suporte de significação contextualizado no sistema, pois, é impossível atingir o sentido do deôntico sem estabelecer esses vínculos de coordenação e de subordinação, axiomas interpretativos que conferem validade às proposições. São nestes vínculos associativos que poderemos hierarquizar as normas e seus valores, trazendo-a ao sistema como unidades válidas, constituintes do conjunto prescritivo. Em termos semânticos e pragmáticos, porém, o ordenamento é aberto, permitindo diversas formas de expressão. Tais calibrações do discurso normativo irão influenciar fortemente na construção do signo representativo destas mensagens.

Tudo isso pressupõe, no entanto, um agente intercalar, pois a comunicação não se dá sozinha, só ocorrerá porque e na medida em que tenha o homem como intermediador movimentando as estruturas lingüísticas. Sem ele, a comunicação perde sua fonte automotriz. É mais, dado que o Dircito é essencialmente comunicação, com o objetivo específico de prescrever condutas, sua relação sígnica se dá entre homens, estes tidos como intérpretes do mundo real, fontes e destinatários da produção normativa.

É o homem, como instrumento dinâmico do Direito, que, por métodos intelectivos, possibilita a constituição de sua realidade jurídica e a prova atua neste sentido como procedimento técnico para a obtenção de tal fulcro. O objeto, em nenhum momento, terá participação ativa na construção da realidade juridica, visto que, como algo fisico do mundo, não pensa, não conceitua, não emite proposições. É sempre o homem, e isto está subliminarmente entendido nas afirmações feitus pela teoria tradicional sobre a prova, a fonte ativa da constituição dos fatos através das provas, por mais que o estímulo primeiro de sua atuação se deu pela percepção de um objeto no mundo.

Sem o homem como "tradutor proposicional" da realidade existencial em juridica, é impossivel alcançarmos as formas lógicas e semânticas do direito. Entendendo o Direito como comunicação, linguagem e texto, será na figura dele que iremos encontrar as chaves da compreensão deste todo sistemático, resolvendo desde os problemas ontológicos até os estruturais do Direito Positivo e. incluindo nestes, os da prova jurídica.

Sob este enfoque c por esta razão que afirmamos serem os fatos descritos pela prova, em verdade, construções intelectivas do intérprete. Serão fatos parciais, nos quais, através do comportamento seletivo das partes sobre os objetos reais, estes passarão por um interpretação, resultando um novo objeto, constituindo $\mathrm{cm}$ termos das necessidades, emoções, personalidades e padrões cognoscitivos próprios daquele que o submeteu a análise. Neste viés, as provas, como retrato desta ação discursiva do 
intérprete, nada mais são que argumentos intelectivos, que objetivam projetar na mente de outrem uma imagem, que não coincide com aquela do real. ${ }^{3}$ Entendida esta dicotomia. percebemos que provar algo é emitir proposição sobre algo e, por isso, prova será sempre discurso e linguagem.

\section{A árdua tarefa de conceituar a prova}

Há que se ter em mente da prática jurídica, que o vocábulo prova traz uma infinidade de acepções. Na tentativa de defini-la, recortá-la-emos, definindo-a em sua amplitude de signilicação e seus instantes discursivos. Neste sentido, será dividido em sentido lato e em sentido estrito. A prova lato sensu é proposição e se produz em dois distintos momentos comunicacionais: (i) um que acontece em âmbito social a protoprova - e (ii) outro em âmbito jurídico - a prova stricto sensu. É no relacionamento entre estes dois mundos que se constitui o amplo contexto do discurso das provas. Não há norma, sem uma fonte enunciativa não-jurídica que a antecede, razão pela qual a prova em sentido estrito pede pela proto-prova para se constituir como norma.

Cumpre alertar que só há sentido diferençar o processo-enunciativofactual (de produção da proto-prova em âmbito social) e o processo-enunciativonormativo (de constituição da prova stricto sensu) em termos lógicos e nãocronológicos. Inexiste separação cronológica dos planos comunicacionais, nos casos em que os sujeitos enunciativos destes sejam coincidentes na mesma pessoa. São momentos distintos em termos lógicos mas ocorrem sucessivamente no tempo. Mais para frente, voltaremos a este ponto.

A proto-prova é uma estrutura peculiar do mundo social, que ainda não integrou o sistema normativo como unidade juridica de significação. Faltam-lhe os requisitos de norma, que só quando transpor a fronteira que separa esses mundos, do ser ao dever-ser, os adquirirá. Não são atos normativos, mas atos sociais de comunicação factual. A condição única destes, portanto, é tão-só a inteligibilidade da mensagem, que necessita organização e disciplina discursiva.

Na proto-prova, encontraremos tanto o sentido de movimento para frente, o mesmo que quer criar uma nova estrutura, qual seja, a prova; quanto o de anterioridade, visto que a proto-prova, em termos lógicos, dá-se sempre e impreterivelmente em momento precedente à prova. A finalidade da proto-prova é a obtenção de enunciado prognóstico da prova, chamemo-lo de "proto-norma" Na proto-

dissonància filosófica entre evento e fato. 
prova, qualquer sujeito pode adquirir a posição de emissor enunciativo, visto que ainda não há norma jurídica veiculando competência; há tão-só sua enunciação.

Por sua vez, a prova será vista como uma categoria jurídica que prescreve as técnicas de direito para relatar em linguagem normativa os acontecimentos concretos e possibilitar a positivação da obrigação jurídica. É, portanto, entendida aqui como unidade jurídica de significação, pertinente ao sistema normativo. É na prova stricto sensu que encontramos a formulação do enunciado normativo que constitui o antecedente - fato jurídico tributário - da norma exacional. Sem a prova, como norma enunciativa de um fato, não há que se constituir a relação jurídica obrigacional, visto que aquele é condição jurídica deste.

Neste sentido, como parte e submisso aos padrões do ordenamento positivo, é examinando as três dimensões semióticas do enunciado probatório - sintaxe, semântica e pragmática - que poderemos identificar se o vocábulo "prova" é empregado como norma, unidade válida de direito, ou como uma não-norma ou pré-norma (protoprova), forma lingüística fora do sistema jurídico.

\section{A desconstrução do conceito tradicional de prova}

Toda esta estrutura jurídica colocada como premissa para a definição do que é prova tem como pressuposta a idéia de que o ordenamento positivo é um sistema de linguagem e, por esta razão, o objeto na sua concretude existencial se torna intangível para ele. O que se entende por objeto no direito é justamente o fruto do discurso jurídico. Os objetos jurídicos (o fato), portanto, nascem somente e no mesmo momento em que se há o relato em linguagem competente (linguagem das provas). O discurso, neste sentido. é o que dá significação ao objeto no Direito Positivo. O fato é fruto de uma operação lógica de seleção e de subsunção, que constrói a própria realidade jurídica. Eis porque o direito, na tentativa de descrever o existencial, confere nova identidade ao evento. Estabelecendo categorias, ele seleciona especificas características indicativas (indices) daquilo que acredita ser relevante para a determinação do fato jurídico (aspecto valorativo) e enuncia-as no antecedente da norma geral e abstrata (hipótese normativa) como modelo referencial para o intérprete na produção da norma individual e concreta.

Na prova, essa relação categorial entre o signo escolhido pelo Direito para constituir o objeto jurídico a partir do evento será sempre indicial, pois a prova é prova de algo impreterivelmente. O indice no Direito poderá ser a norma (antecedente da norma) ou a palavra técnica empregada para determinar a forma juridica ou mesmo çualquer expressão lingüística indicativa das características enunciadas para distinguir o 
fato jurídico. No processo ou no procedimento tributário, nenhuma questão de fato poderá ser juridicamente solucionada sem o uso de algum signo que the sirva como indice e isto só será possivel através da linguagem das provas. Por assim dizer, a doutrina tradicional peca ao realizar a dissociação entre prova e índice. O certo é que, no Direito, nunca encontraremos norma probatória desprovida da qualidade indicial.

Da mesma forma, o Direito, como linguagem rígida, exige precisão da mensagem. Tal é a justificativa de se ter a linguagem escrita, aquela presente nos diferentes procedimentos e processos jurídicos, como a única capaz de atender a estes requisitos formais do Direito. Assim sendo, todas as provas serão sempre documentais. Por este viés. "Prova" poderá ser entendida tão-só como aquela estrutura presente nos autos na forma documental que lhe faça expressão lingüística, suporte fisico de significação. Neste sentido, é descabida a classificação das provas em materiais, testemunhais ou documentais, visto que todas as provas, em todos os momentos, serão documentais.

E mais, se Direito é linguagem e no processo só se integram provas documentais, cabe somente ao homem, como produtor intelectivo deste mesmo texto, o qualificativo de "fonte" É na figura do homem que se verifica a mola propulsora da constituição da realidade jurídica. Sem a presença ativa dele, não se dá a incidência normativa, a positivação das condutas, a constituição dos fatos jurídicos; enfim, sem o homem não há Direito. Por assim dizer, na articulação dos enunciados jurídicos, os sujeitos se relacionam entre si como emissores e receptores de mensagens e não entre ele e as coisas. Os homens serão sempre fontes ativas da prova; e, por conta disso, estas serão sempre resultados da ação destes. A prova, portanto, será invariavelmente pessoal.

Por fim, vale frisar que o Direito não procura a verdade dos fatos, mas a constituição de norma válida, capaz de compelir o comportamento de alguém. Por este entendimento, as unidades normativas da prova não buscam a verdade e/ou falsidade dos eventos factuais, mas a constituição jurídica dos fatos dentro do bit validade/invalidade. No processo enunciativo-normativo da prova stricto sensu, a finalidade buscada é, em nível imediato, a constituição do fato jurídico tributário por meio das provas, e, em termos mediatos, a formação do vínculo implicacional prescritivo de conduta e formador da norma individual e concreta.

Observamos que muitos cientistas do Direito entendem que a finalidade da prova é a busca da verdade. No entanto, só poderemos a compreender desta forma quando definirmos o conceito de "verdade" confluindo os três contrapontos filosóficos deste instituto na teoria da prova - a "verdade" por correspondência, por coerência e 
pragmática. Verificaremos que estes entendimentos se conjugam para explicar o que realmente se pode ter com a busca da verdade no direito positivo.

De formam sumária, concluiremos que, "verdade", para o Direito, ou melhor a finalidade da prova para o direito será a busca por um modelo signico que se adeque às três verdades o que se reflete na prática pela definição de um fato jurídico coerente com o sistema (1), consensualmente admitido pelas partes (2) e que guarde uma correspondência mínima com a causalidade física do mundo existencial (3). Isto sim será a verdade dos fatos - finalidade das provas - para o ordenamento positivo, conceito que se difere do que é tradicionalmente colocado, geralmente levando em conta tão-só a verdade por correspondência. As unidades normativas da prova buscam. portanto, em nível imediato. a constituição do fato jurídico tributário por meio das provas. e, em termos mediatos, a formação do vínculo implicacional prescritivo de conduta e formador da norma individual e concreta exacional.

Por todo exposto. podemos concluir e afirmar que. ao contrário do que a doutrina tradicional dispõe, a prova será sempre (i) documental, única forma capaz de preencher os requisitos formais do Direito; (ii) pessoal, vez que a mensagem probatória prescinde do homem legalmente competente como elemento intercalar; (iii) ativa, como expressão da ação e da atividade intelectiva do homem na constituição da realidade jurídica, (iv) indicial, pois o signo normativo será sempre uma reconstrução lingüística indicativa do real e, por fim. (v) a finalidade da prova será a busca por um modelo sígnico que se adeque às três verdades: por coerência, por correspondência e pragmática.

5. Ato, procedimento e norma: uma proposta de acepção trazida da Filosofia do Direito

Ainda com o fulcro de entender o fenômeno complexo da prova no Direito, trouxemos da Filosofia importante sistema interpretativo. Percebemos que, na tentativa de definir a prova, chegamos a uma encruzilhada na qual ficou impossível compreendê-la sem associá-las às idéias de: ato, procedimento e norma, como acepções semanticamente válidas, alternando-se apenas o momento enunciativo que se pretende destacar.

Na proto-prova, poderemos designar: (i) o ato como a ação constituinte do texto que o sujeito pretende ver como norma: (ii) o procedimento como o conjunto seqüencial de atos de fala do sujeito enunciativo, direcionados, unitariamente, para a determinação da proto-norma; e (iii) a norma como a regra técnica enunciativa. expressão do fenômeno comunicativo factual. 
Na prova siricto sensu, por sua vez, poderemos definir: (i) o ato como a estrutura de significação da ação normativa. ou seja, àquele último do procedimento em que se vê a atividade de produção da norma prescritora de conduta como pronta e acabada; (ii) o procedimento como os passos a serem seguidos pelo exegeta do Direito que viabiliza a produção de ato-normativo válido no sistema; e (iii) a norma como a regra técnica do Direito que funciona como requisito necessário para a produção do ato ação - e do procedimento - atividade - probatórios. Há de se ter em mente que, em toda prática probatória, em termos normativos, encontraremos, no mínimo, as três acepções da proto-prova e da prova stricto sensu, como ato, procedimento e norma, sentidos estes passíveis de conviver sem que haja desconfirmação de um com outro. $\mathrm{E}$ mais, como resultado deste processo, é que iremos verificar o contexto amplo da prova: a norma probatória lato sensu.

\section{O conceito de norma juridica probatória ou a prova stricto sensu}

Observado o contexto epistemológico ora proposto, entendemos que, antes mesmo de ingressar no que se entende por norma probatória, importante conceituar o vocábulo "norma" isoladamente. É observando a expressão mínima e irredutivel do corpo da norma-jurídica, que conseguiremos alcançar a base estrutural de toda ¿ qualquer unidade de sentido deôntico da prova - a prova em sentido estrito.

Neste trabalho. a norma juridica será considerada como uma estrutura lógica de significação que o intérprete do direito constrói a partir da leitura dos enunciados lingüísticos, ${ }^{4}$ tal qual anuncia Paulo de Barros Carvalho. É uma estrutura mínima e irredutível de manifestação do Direito Positivo, onde encontramos não somente a unidade de significação, pura e simplesmente, como, também, a própria estrutura lógica do sistema normativo modalizada em sua forma mais simples. Fm outras palavras, em toda norma jurídica encontraremos não só o seu significado específico como, também, todo o sistema normativo a que ela se subordina, condição da sua própria validade como signo jurídico.

Desta forma, ainda que tenham funções diferentes no ordenamento, todas as normas se apresentam com a mesma forma lógico-juridica, variando apenas em sua significação, razão pela qual dizemos que o Dircito é sintaticamente homogêneo e semanticamente heterogêneo.`

- CARVAlho, Paulo de Barrus. O direito positivo como sistema homogêneo de enunciados deônticos. Revista de Direito Tributário. São Paulo, a. 12, n. 45. p. 35, jul./set. 1988.

5 Confira entendimento do prof. Paulu de Barros Carvalho sobre o assunto: "Seu discurso se organiza em sistema e. ainda que as unidades exerçam papéis diferentes na composição interna do conjunto (normas de conduta e normas de estrutura), todas elas exibem idêntica arquitetura formal. Há homogeneidade. mas 
Reitero que o sistema jurídico é constituído por uma linguagem técnica. No plano lógico-sintático, constrói a norma associando variáveis e constantes lógicas, signos desprovidos de significados específicos, mas que apontam para este ou aquele objeto. É formalizando que o direito consegue criar instrumentos lógicos capazes de abarcar toda e qualquer conduta, bastando simplesmente ao exegeta preencher a fórmula com novas unidades de significação (o conteúdo). O importante agora é lembrar que toda formalização é um arbitramento de signos, desprovidos de significação concreta. Na fórmula, prioriza-se a demonstração dos vínculos associativos, deixando de lado tudo o quanto envolve os conteúdos propriamente ditos.

Fm linguagem formal, a norma será estruturada da seguinte forma:

$\mathrm{D}[\mathrm{F} \rightarrow(\mathrm{Sa} R \mathrm{Sp})]$

Traduzidos estes símbolos conforme as referências abaixo:

"D": Modal deôntico que expressa o "Dever-ser" em sua função neutra (constante lógica); é o que confere validade à norma juridica;

"F": Hipótese normativa, descritiva do fato juridico ou simplesmente descritor; prótase ou pressuposto (variável lógica);

" $\rightarrow$ ": Nexo de causalidade juridica que estabelece uma relação-de-implicação entre hipótese e tese (constante lógica);

"(Sa R Sp)": Tese normativa, prescritiva de conduta, ou simplesmente prescritor, conseqüiente normativo ou conseqüência (variável lógica);

"Sa": Sujeito ativo da relação jurídica (variável lógica);

"R": Modal deôntico no interior da estrutura proposicional da tese, cujos valores são $\mathrm{O}$ (obrigatório), $\mathrm{V}$ (proibido) e $\mathrm{P}$ (permitido) (variável lógica relacional);

"Sp": Sujeito passivo da relação jurídica (variável lógica);

Tomando esta noção que poderemos qualificar a norma probatória dentro de seus contextos comunicacionais e identificar na prova stricto sensu todos estes elementos que a constitui. Tal mecanismo corrobora com a precisão da análise não-

homogeneidade sob o ângulo puramente sintático, uma vez qui nos planos semântico e pragmático o que se dá é um furte grau de heterogeneidade, único meio de que dispõe o legislador para cobrir a imensa e variável gama de situações sobre que deve incidir a regulação do direito, na pluralidade extensiva e intensiva do real-social". CARVALHO, Paulo de Barros. O direito positivo como sistema homogêneo de enunciados deônticos. Revista de Direiro Tribulurio, São Paulo, a. 12, n. 45, p. 36, jul./set. 1988. 
somente confirmando a validade do signo como também convalidando a diferenciação da proto-prova à prova stricto sensu.

Importante notar que mesmo dentro das especificidades já alcançadas por este trabalho, o vocábulo "prova" inserto puramente em sua acepção de norma, poderá ter diversas interpretações que the conferiram amplitude semântico-normativa mais ou menos larga, de acordo com sua função normativa maior ou menor na incidência da norma individual e concreta da exação.

Neste sentido, a prova poderá se qualificar por diversos vieses (i) de um lado, poderá ser a norma reguladora de conduta, que porta em seu antecedente o fato juridico tributário e, em seu conseqüente, a relação jurídica implicacional da obrigação tributária (norma individual e concreta); (ii) de outro, poderá ser a norma constituinte do fato jurídico tributário, mas ainda não sendo a norma da exação propriamente dita; (iii) em terceiro, poderá ser entendida como a norma que viabiliza o ingresso de outras normas no ordenamento (norma geral e concreta); (iv) da mesma forma, também se qualificará como a norma que prevê o procedimento formal de constituição do alicerce comunicativo (deveres instrumentais); ou, por último, (v) a norma que contém a previsão abstrata do fato que dá fundamento de validade para aquelas outras que constituiram outras regras probatórias (norma geral e concreta).

Todas estas acepções são perfeitamente aceitáveis uma vez que tudo depende do sistema de referência que o intérprete adotou. Quando escolher uma noção mais abrangente e suas premissas forem da mesma forma amplas neste mesmo sentido será viável. No entanto, iremos nos ater aqui à acepção de norma probatória como aquela unidade que ainda não constitui a norma individual e concreta da exação, mas é norma individual e concreta que faz ingressar o fato jurídico tributário em seu conseqüente normativo.

Neste sentido, a norma probatória, como regra técnica, seria estruturada, sintático e semanticamente. da seguinte forma: "Se efetuados os procedimentos determinados em lei dentro do prazo e apresentados à autoridade legal na forma préestabelecida; então o sujeito receptor da mensagem jurídica deve aceitar como juridicamente constituído o fato tributário ditado pelo enunciatário da mensagem normativa" Dentro de sua estrutura simbólica encontraríamos a seguinte subdivisão:

"D": modal deôntico que expressa é norma juridica, inserta e válida ${ }^{6}$ no sistema.

" Dizer tão-só "norma válida" já quer signilicar norma pertinente e inserta no sistema. No entanto, valho-me desta tautologia para justificar o meu entendimento quanto à noção de validade. 
(1) No antecedente da norma: "Se efetuados os procedimentos determinados em lei dentro do prazo e apresentados à autoridade legal na forma pré-estabelecida $(\ldots) ; "$

"F": efetuar (obrigação de fazer) os procedimentos legalmente prescritos (prazo, forma e publicidade) para a constituição do fato jurídico;

" $\rightarrow$ ": nexo de causalidade jurídica que estabelece que se for cumprida esta obrigação de efetuar o procedimento nos moldes da lei, dá-se, por conseqüente lógico-jurídico, a relação obrigacional;

(2) No conseqüente da norma: "(...) então o sujcito receptor da mensagem jurídica deve aceitar como juridicamente constituído o fato tributário ditado pelo enunciatário da mensagem normativa"

"(Sa R Sp)": conseqüente normativo que constitui o fato tributário ditado pelo enunciatário da mensagem normativa:

"Sa": o sujeito reccptor da mensagem jurídica;

" $R$ ": modal deônticu no interior da estrutura proposicional da tese, cujo valor no caso é obrigacional (o):

"Sp": enunciatário da mensagem normativa;

Neste diapasão, é estruturando a norma individual e concreta da prova que iremos verificar o fato jurídico tributário. Por conseqüência lógico-normativa, a própria existência desta norma, trará à tona a produção implicacional de outra norma que é a própria estrutura individual e concreta que formaliza a relação jurídica tributária da exação entre contribuinte e Fisco. O conseqüente da norma probatória servirá de alicerce comunicativo de enunciação da norma individual e concreta exacional e será empregado como o antecedente desta norma.

Apenas para diferençar estas duas normas individuais, verificamos que, no caso de norma exacional, tratando-se de uma hipótese de incidência de IPTU, de competência da municipalidade de São José clo Rio Preto, conforme dispositivos da Lei municipal n. 3009, de 10/10/96 D.M. 15/10/96, a estrutura desta norma individual e concreta ficaria desta forma: "Dado que uma pessoa seja proprietária de imóvel no perímetro urbano do município de São José do Rio Preto no ano-base de 2006, então deve ser a relação juridica tributária entre o proprietário e a municipalidade, devendo aquele efetuar o pagamento de $1 \%$ do valor venal do imóvel"

Sendo que:

"D": modal deônticu que expressa é norma jurídica válida no sistema. 
(1) No antecedente da norma: "Dado que uma pessoa seja proprietária de imóvel no perímetro urbano do município de São José do Rio Preto no ano-base de 2006 (...);"

" $F$ ": ser proprietário de imóvel no perímetro urbano do município de São Josć do Rio Preto no ano-base de 2006;

" $\rightarrow$ ": nexo de causalidade juridica em que, quando constituído o fato, deve-ser a relação implicacional de tributação;

(2) No conseqüente da norma: “(..) então deve ser a relação juridica tributária entre o proprietário e a municipalidade, devendo aquele efetuar o pagamento de $1 \%$ do valor venal do imóvel."

"(Sa R Sp)": conseqüente normativo que constitui a referida relação obrigacional entre o proprietário e a municipalidade, devendo aquele efetuar o pagamento de $1 \%$ do valor venal do imóvel;

"Sa": o proprietário;

"R": modal deôntico no interior da estrutura proposicional da tese, cujo valor no caso é obrigacional:

"Sp": a municipalidade de São José do Rio Preto;

A partir desta estrutura, por inferência lógico-dedutiva. poderemos montar a norma probatória que constituiu o fato jurídico-tributário. Será gramaticalmente colocada da seguinte forma: "Efetuada a escritura pública, constituindo o título de propriedade no respectivo cartório de bens e imóveis da zona daquele bem imóvel, na forma legal pré-estabelecida; então a autoridade jurídica e terceiros devem aceitá-lo juridicamente constituído como sujeito de direito proprietário deste bem. com todas as suas garantias crga omnes sobre o imóvel"

Há de se perceber que as duas frases acima apresentadas são semanticamente bem diferentes. Uma coisa, portanto, é a norma tributária da exação; outra diferente é a norma jurídica probatória constituinte do fato.

Entendido isto, outro aspecto a ser mencionado neste domínio é que, como norma individual e concreta, a prova pedirá uma norma que lhe confira fundamento de validade e outra que the faça veículo para se integrar no ordenamento; são respectivamente a norma geral e abstrata e a norma geral e concreta da norma probatória. Tal é a razão de não ser semanticamente inválido entender a prova como a previsão abstrata da norma probatória ou como a norma introdutora probatória. São inferências umas das outras de maneira que é impossivel imaginar uma norma jurídica sem integrála neste contexto normativo. 
Da mesma forma que, considerando a norma probatória como o próprio fato juridico, pressuposto normativo da norma individual e concreta, não há erro grosseiro imaginar, num contexto mais amplo, a norma probatória como o estabelecimento do próprio vínculo tributário exacional entre as partes. Em outras palavras, a participação do exegeta do Direito na constituição da realidade jurídica é especialmente fundamental no primeiro momento, que é aquele em que se constituí o fato jurídico tributário. A “ $\rightarrow$ ” que expressa o nexo de causalidade juridica, dá-se, por sua vez, automaticamente no mundo jurídico. Isto porque ela, uma vez fundamentada em fato juridico constituido em linguagem competente, dá-se por conseqüência lógicojurídica. Confira entendimento de Lourival Vilanova sobre o assunto:

Inexiste, pois, no universo das proposições jurídicas, necessidade lógica ou factualmente fundada de a hipótese implicar a tese ou conseqüência. É. a própria norma que põe o vinculum, é a fonte formal do Direito que, fundando-se num ato de valoração, estatui como devendo ser que a hipótese implique o conseqüente. Sem norma válida o nexo desfaz-se. ${ }^{7}$

Neste sentido, por inferência lógica, é possivel entender também que uma vez constituído o fato $\mathrm{e}$ instala-se este processo de incidência normativa automaticamente dentro do contexto jurídico, o resultado deste processo a a norma individual e concreta da exação - poderá representar o todo procedimental, no qual se inclui o conjunto dos atos e normas probatórias.

Eis que é difícil tomar uma posição sobre qual a referência normativa probatória mais correta, considerando que, em qualquer decisão, haverá um efeito direto na atividade cognitiva a que se dispõe conhecer o exegeta do direito: ora aumentando o campo de reflexão da realidade jurídica tratada ora diminuindo-o. Neste trabalho, a idéia não é inovar mais apenas expor toda a complexidade jurídica que o instituto probatório pode abarcar, alertando a quem se dispõe conhecê-lo perceber todas estas peculiaridades semânticas contidas numa só estrutura que é a prova.

\section{A correlação lógica entre os deveres instrumentais e a prova}

Para transpor as bases teóricas e prescrever condutas. o Direito requer um alicerce objetivo de comunicação jurídica que o constitua de forma a permitir a regulação das condutas. Há diversas formas de fazê-lo, no entanto, em todos, o sistema jurídico pede uma série de atos instrumentais que viabilizem a transmissão da mensagem

VILANOVA, Lourival. Estruturas Lógicas c' o Sistema do Direito Positivo. São Paulo: Noeses. 2005. p. 92 
legislada. Eis os deveres instrumentais. A função dos deveres instrumentais é imprescindível na teoria das provas e contribui para fazer valer a incidência tributária, visto que é o suporte físico desta comunicação juridica. Sem eles não se transmite a mensagem legislada e, conseqüentemente, o direito deixa de cumprir sua missão: regular condutas.

Diante do teor comunicacional do Direito, o ordenamento jurídico se viu na necessidade de criar categorias instrumentais com a função de formar a base objetiva da comunicação jurídica e possibilitar posterior expedição da norma tributária. A obrigação tributária requer. portanto, uma linguagem que a constitua de forma a permitir a incidência. Pede uma série de atos instrumentais que viabilizem a comunicação.

Eis a razão que justifica a posição do sistema jurídico em priorizar e sancionar fortemente aqueles que descumprem as obrigações que instituem os deveres instrumentais ${ }^{8}$ (comumente chamados de deveres acessórios ou obrigações acessórias). São, portanto, esses documentos escritos que formarão a base necessária para o Fisco atuar no exercício de suas competências tributárias. Assim já o bem assinalou Paulo de Barros Carvalho dizendo que "o direito substantivo tributário, sem tais deveres instrumentais, é cego, e estes sem aquele são vazios. Na ausência de deveres formais não há incidência das normas de direito material, não há efeitos, nem crédito tributário, nem débito fiscal, nem produção normutiva, nem prova, e, tampouco, a segurançu juridica que a ordem positiva visa a estabelecer" "

Os deveres instrumentais ou formais. portanto. são os pressupostos de toda atividade da autoridade no controle e na manutenção dos direitos e deveres dos contribuintes, garantindo o principio da estrita legalidade inerente ao Direito Tributário. Eles favorecem e viabilizam o exercício da gestão tributária da Administração Pública na busca da melhor adequação do suporte fáctico à previsão geral e abstrata da norma tipificadora da exação. Facilita o próprio exercício público de constituição. fiscalização e atuação da atividade da Administração Pública. E, neste sentido, eles serão normas impositivas de obrigações de fazer direcionadas aos particulares com o objetivo de facilitar a atividade de gestão da Administrativa Tributária. E é aqui que iremos encontrar as provas como reflexo deste ato instrutório e informativo da fiscalização e do Poder do Estado. Tanto a expressão deveres instrumentais quanto prova referem-se à

Assim determina $u$ art. 113 do CTN que dispōe em scu $\S 3^{\circ}$ que "A obrigação acessória, pelo simples fato da sua inobserváncia, converte-se em obrigação principal relativamente à penalidade pecuniária" $\mathrm{O}$ Código, assumindo a importància destas categorias na compostura da exação tributária, equilibra a sua infração com aquela própria da instituição do tributo - obrigação principal conferindo mesmo peso a ambos desvio de conduta. Eis uma observação do aspecto valorativo do sistema.

9 CARVAI HO. Paulo de Barros. Curso de Direito Tributário. 10. ed. São Paulo: Saraiva, 1998. p. 204-207 
constituição do fato jurídico tributário, o qual serve de pressuposto para a imputação prescritiva de conduta. Eis que um está intrinsecamente ligado ao outro.

Sem que o contribuinte preste informações à autoridade administrativa quando solicitado. notifique toda transação comercial de seu estabelecimento em livro próprio ou diário. emita nota fiscal na saída de mercadoria de se estabelecimento, preste declaração de período em período, não há que se falar em fato jurídico e em incidência da norma jurídica tributária. Todos estes documentos emitidos serão o pressuposto comunicativo e a base objetiva, por se tratar de texto, que preparam a constituição da norma. São atos formadores de prova e realizadores dos deveres instrumentais, porém ambos constituem o fato jurídico.

Os deveres instrumentais no Direito Tributário. portanto, cumprem esta propriedade constitutiva do próprio ato normativo. Sem eles, em sua formalidade concreta, não há incidência da norma tributária e, por assim dizer, o direito se esvai no tempo e no espaço.

8. O ato administrativo e a prova: similaridades conceituais

Apresentadas as várias formas em que se pode entender a prova como norma, cumpre firmar que, neste estudo, entendemos que a acepção mais correta é a de norma probatória como aquela unidade que ainda não constitui a norma individual e concreta da exação, mas é norma individual e concreta que faz ingressar, em seu conseqüente, o fato jurídico tributário no ordenamento positivo.

Elegendo este conceito como oriente, percebemos que, em vista das proximidades conceptuais e funcionais, importante ferramenta metodológica é associar a prova ao ato administrativo. Como atos normativos, ambos instrumentos são estruturas jurídicas de significação. Assemelham-se a tal ponto de verificarmos tanto no ato administrativo tributário quanto na prova a polissemia processo/produto, mesmo tomando-os tão só como norma. Neles, podemos identificar as marcas da enunciação (proto-norma) como, também, o produto delas (norma), ou especificando melhor. a norma individual e concreta. Por esta razão, as palavras ato administrativo tributário e prova, em sentido largo, serão o gênero que envolve duas espécies: o processo e o produto normativo.

Analisar o ato administrativo tributúrio e a prova pressupõe, portanto. dois momentos epistemológicos que serviram de guia interpretativo:

(i) o texto, a norma individual e concreta de onde se identifica no ato-norma os elementos que integram a 
relação deôntica (de implicação) entre fato juridico e relação jurídica (análise intra-normativa); e

(ii) o contexto jurídico, ou seja, a relação inter-normativa. de onde se identifica a operação de subsunção e os pressupostos procedimentais presentes na estrutura da norma juridica válida.

Neste trâmite do processo de positivação - da confecção da norma probatória até à norma exacional - encontraremos diversos pontos relevantes constituintes do texto inerente a este complexo factum comunicacional do direito:

(i) A motivação ou a descrição do motivo do ato " $F$ ":

É o lugar e o momento em que as provas irão estruturar o enunciado do fato juridico, com base na hipótese normativa, alocando-o no conseqüente da norma probatória e no antecedente normativo da norma exacional;

(ii) O sujeito enunciador ou emissor da norma:

O emissor da norma jurídica, ou melhor, pessoa de direito legalmente atribuida da competência para expedir unidade de sentido deôntico. É a mesma entidade que irá subsumir o fato jurídico à norma e estabelecer, coimplicacionalmente, o vínculo relacional juridico tributário entre as partes:

(iii) O sujeito receptor ou destinatário da norma:

O destinatário da norma. ou seja, aqueles que figuram nos pólos da relação obrigacional tributária, ou seja. Fisco e contribuinte;

(iv) O nexo normativo relacional da norma:

A variável relacional escolhida pelo sujeito emissor que estabelece o vinculo obrigacional, intra-normativo, entre os sujeitos Sa e Sp da norma exacional;

(v) A conduta prescritiva modalizada pelo relacional:

Os efeitos diretos da determinação do fato jurídico, que se dão automaticamente na composição sintática da proposição juridica.

Vale salientar a propósito que, ao longo deste trabalho, vamos construindo o Direito como um amplo processo discursivo, portanto, interação entre duas pessoas, fixando-se, concomitantemente, a relação entre quem fala e quem ouve. $\mathrm{O}$ direito, neste sentido, é o resultado dessas diversas relações interpessoais entre oradores e ouvintes, enquanto órgãos habilitados para constituir a mensagem jurídica. $\mathrm{E}$ ao falar, num processo constante de definição de relações, que suporemos os próprios utentes da 
linguagem jurídica como os entes que irão determinar as questões de Direito, o universo jurídico e os valores normativos. A norma, nesta concepção, surge como o discurso, ou melhor, a mensagem legislada constituída por um processo dialético e, por assim dizer, é um exercício que se abriga no plano do intelecto. Por estes torneios, não corremos no mau vezo de afirmar que tudo no Direito surge deste processo dialógico e, para além do rigor, é fruto de uma inteleç̧ão do mundo em sua concretude existencial. No âmbito probatório, isso será latente. Tal é a justificativa que permite a afirmação de que o Direito não incide sobre os eventos propriamente ditos mas sobre as provas deste evento, sobre os enunciados que construíram linguisticamente aqueles fatos no mundo jurídico. Logo, levemos em conta essas injunções para cravar. uma vez por todas, a premissa de que o direito incide sobre as provas e não sobre os eventos por elas traduzidos em linguagem jurídica.

Em comentário ligeiro, vale salientar ainda que é do contexto que se valora a unidade de significação fruto do processo dialético, qualificando-a dentro do bit jurídico-normativo em válido ou não-válido (inválido). Dentro do texto, entendido como discurso ou ato-de-fala, encontramos esta implicitude do contexto do Direito posto como um conjunto sistemático indissociável. A análise contextual é o momento em que vamos nos deparar com a dinamicidade do sistema, de onde normas jurídicas se entrecruzam para constituir uma significação fundamentada no sentido do conjunto como um todo.

Dentre os requisitos extrínsecos e contextuais do ato administrativo e da prova stricto sensu, iremos encontrar:

(a) Autoridade ou agente competente:

$\mathrm{O}$ sujeito produzirá enunciados normativos apenas e na medida em que tenha atribuições conferidas pelo ordenamento para tanto. No Direito Tributário, por se tratar de um sub-ramo do Direito Público, as regras competenciais deverão ser observada com maior rigor. Há dois sujeitos indicados pela lei como capazes de enunciar: a Administração Pública e u contribuinte. As duas figuras assumirão na figura do agente capaz um sentido yue lhe é próprio de competência normativa.

(b) Objeto lícito:

A licitude ou ilicitude da prova encontrar-se-á sempre no procedimento constituinte da norma individual e concreta probatória do fato jurídico tributável. É nele que poderemos encontrar as bases objetivas para qualificar ou desqualificar a prova como ato normativo nulo, pois desrespeitados os pressupostos contextuais inerentes à constituição da prova no Direito e aos limites sistemáticos 
procedimentais. Eis a confirmação de que o erro não se encontra na norma probatória, mas antes dela, no próprio procedimento constituinte da norma.

(c) Procedimento previsto em lei:

A marcha de atos enunciativos, coordenados seqüencialmente por um escopo comum, sob a forma e os ritos legalmente previstos. Traduzem-se concretamente em todos os atos e/ou providencias - intelectual ou material produzidas por sujeitos enunciativos competentes para preparar a expedição da norma individual e concreta, apresentando-os na linguagem jurídica. É na linha diretiva da Constituição Federal que haverão de pautar-se todos os atos administrativos componentes deste procedimento.

(d) Publicidade:

Somente através da publicação dos atos, e neste momento, que a norma se realiza, como enunciado jurisdicizado. É, portanto, o último e o mais importante instante do procedimento normativo, sem o qual a norma juridica inexiste para o ordenamento juridico. Cumpre esclarecer que o sentido do termo "publicidade" implica não a condição concreta de consciência do destinatário ou mais ainda sua manifestação, mas pressupõe tão simplesmente a existência de pelo menos a possibilidade de conhecimento pelos meios comunicacionais e procedimentais, previstos pelo sistema normativo, daquele que se vê diretamente afetado pelos efeitos do Direito Positivo transmitida por aquela mensagem individual e concreta reguladora de sua conduta. A publicidade é um ato que garante acima de tudo o devido processo legal firmando o direito do destinatário da mensagem em conhecer o texto da lei, conferindo oportunidade de se manifestar no momento e na medida em que são expedidos os atos normativos. A publicidade é o meio da norma jurídica alcançar o destinatário, transpondo o plano pessoal da consciência do agente para ingressar no domínio das relação inter-pessoais permeadas no mundo social. Só assim, há Direito. norma e prescrição de condutas.

(e) Motivo do ato:

A norma - o texto - não é o querer propriamente dito, mas é o resultado de um querer - o contexto. O querer. apesar de não pertencer dentro da estrutura da norma, é um pressuposto desta e, por isso, confirma o sentido expedido por ela. Sem o querer, portanto, não chegamos às estruturas de signifícação do dever.

(f) Finalidade ou objetivo: 
A finalidade se encontra fora da estrutura da norma, mas compõe o pressuposto exógeno dela. Tal figura entra em paralelismo com uma estrutura interna da procedimento jurídico constituinte da norma que é a própria causa do ato, nexo lógico intranormativo.

\section{Conclusões}

No procedimento administrativo, verificamos que somente com a linguagem das provas, constituindo o fato jurídico que servirá de antecedente da norma exacional, é que poderemos lançar e constituir o tributo. O lançamento atua, portanto, como procedimento prescrito pelo Direito para constituir a realidade jurídica e, ao mesmo tempo, como ato controlador da legalidade da atividade. É pelo exercício intelectual de reconstrução do escalonamento das regras jurídicas de onde se obterá a confirmação da validade das novas estruturas tributárias de significação insertas no sistema pelo lançamento; e é por esta via que se efetivará o controle de legalidade dos atos produzidos, tanto aqueles das autoridades administrativas quanto aqueles outros dos contribuintes.

O lançamento tem por base ato normativo probatório, constituinte de fato jurídico válido para estabelecer o vínculo da relação jurídica tributária. Estamos no domínio da prova stricto sensu, unidade integrante do sistema normativo. Nesta, o sujeito enunciativo deve ser pessoa competente para produzir proposição jurídica. Falar em agente capaz no Direito Público é caracterizar a competência de quem enunciou a norma. Destacamos três situações competenciais no processo de positivação, ocorrentes no procedimento administrativo, que afetam tanto a composição do lançamento quanto sua respectiva norma probatória, intrinsecamente ligada a este.

A todo Lançamento de Ofǐcio, compete à autoridade administrativa (a) a produção de provas para a constituição da norma probatória e seu respectivo fato jurídico tributário; e (ii) a constituição da norma individual e concreta exacional, através do procedimento estipulado no art. 142 do CTN. Passando a ser representada esta capacidade enunciativa da autoridade pública da seguinte forma: 


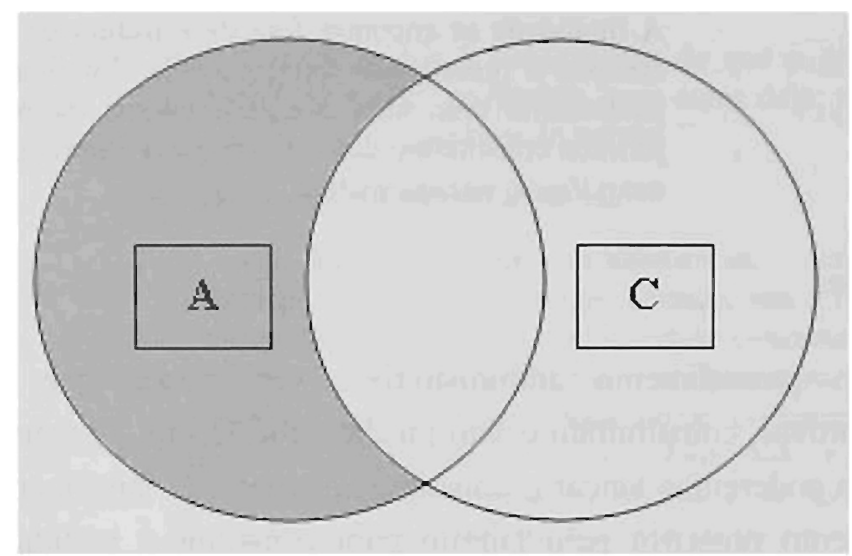

Enquanto a primeira traduz o fato em linguagem juridica competente; a segunda, toma este conseqüente fáctico da norma probatória, realoca-o no antecedente da norma exacional e estabelece o vínculo implicacional entre Fisco e contribuinte. Eis instaurado o laço inter-normativo.

Como poder-dever, cabe a ela, sem exceção, motivar o seu ato, expondo de maneira objetiva e clara os alicerceres documentais (prova) que lhe serviram para a constituição do fato jurídico. Justifica-se esta exigência legal pelo simples motivo de que só desta maneira viabiliza-se ao contribuinte que verifique se houve a correta tipificação e a correta adequação do fato ao preceito normativo geral e abstrato, controlando a legalidade dos atos da administração pública. Quando não estiver devidamente demonstrada e provada a efetiva subsunção da realidade factual à hipótese descrita em lei pelo lançamento de ofício, dá-se por invalidável tanto a norma individual e concreta da prova quanto a norma individual e concreta da exação. Falar-se no art. 142 do CTN em "verificar a ocorrência do fato" significa haver a necessidade de prová-lo, sob todos os meios legalmente permitidos para constituir validamente fato jurídico tributável.

A propósito, vale salientar que, em princípio, para quaisquer efeitos, os dados fornecidos pelo contribuinte à administração fazendária são sigilosos e. por corolário, ela não pode fornecê-los a outras pessoas. Tais suportes lingüísticos poderão vir a sofrer controles administrativos, mas isso não significa que devam se tomar público. Pelo exposto, poderemos diferençar dois tipos de publicidade dos atos: 1) aquela que diz respeito ao conhecimento das partes interessadas e diretamente afetadas pela norma a ser produzida no sistema jurídico; 2) aquele outro que abrange o conhecimento dos atos normativos por todos daquela sociedade. O primeiro, como já observado, é a publicidade que entendemos constituinte da comunicação juridica e pressuposto exógeno da norma jurídica, para toda e qualquer enunciação normativa. $\mathrm{O}$ 
segundo, em contrapartida, é aquele limitado pelo princípio do sigilo de dados que é parte inerente e constituinte da norma. Somente o primeiro deve estar sempre presente na produção de toda e qualquer norma.

No Lançamento por Declaração, o enunciado normativo expedido pela autoridade só ingressará no ordenamento jurídico quando ela promover o lançamento e o sujeito passivo for devidamente notificado, apresentando na seqüência sua declaração; só assim o ato produzirá efeitos jurídicos. Neste domínio, a capacidade enunciativa da norma se encontra ainda na autoridade administrativa, abrangendo, por sua vez, o contribuinte como sujeito enunciativo no processo de enunciação do lançamento por declaração. Graficamente, ficaria representado da seguinte forma:

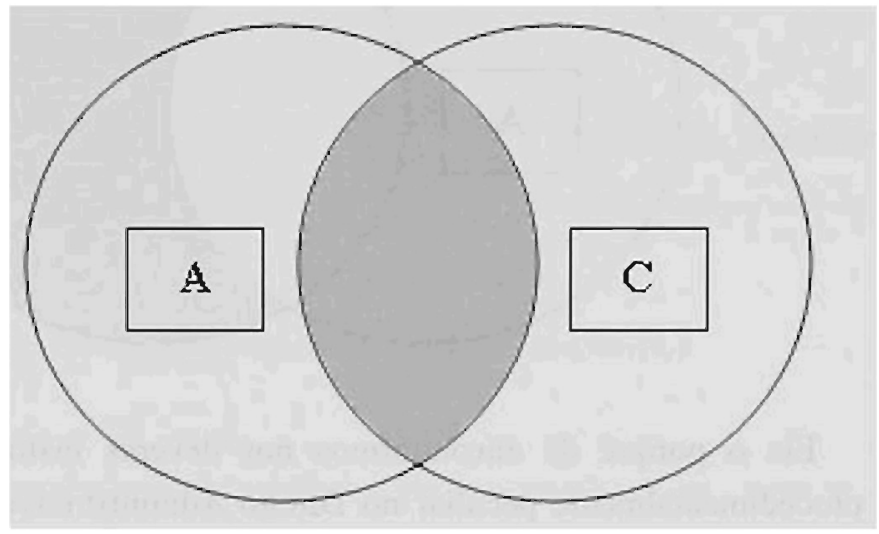

Os atos prestados pelo contribuinte à autoridade não configuram a norma de "lançamento" e, neste sentido, não constituem o fato jurídico e nem mesmo o crédito tributário. São deveres instrumentais que servem tão-só como alicerce comunicativo.

Para que haja a enunciação de lançamento por declaração válido, portanto, há necessidade de participação do contribuinte, como condição enunciativa para a posterior ingresso o enunciado no mundo jurídico. O ato da Administração Pública de lançar tem por base a "declaração do sujeito passivo ou terceiro" e a matéria tratada no documento informativo do contribuinte é "indispensável para sua efetivação", tal qual o anuncia o art. 147 do CTN. Isto é o mesmo que dizer que sem a formalização da protonorma pelo contribuinte, não se tem a condição comunicativa de constituição da norma. Participa o contribuinte no procedimento enunciativo factual enunciando a proto-prova e proto-norma, mas quem é o agente competente para produzir o procedimento enunciativo normativo é somente a autoridade administrativa. Só a ela compete averbar a norma probatória, que constitui o fato jurídico, e a norma exacional, que prescreve a relação jurídica tributária. 
No Lançamento por Homologação, o contribuinte não lança mas introduz enunciado prescritivo no ordenamento pois a própria lei lhe atribuiu competência função constitutiva do fato jurídico tributário e função formalizadora da norma individual e concreta exacional. Pela conjugação do ato do contribuinte com a ciência da autoridade, em qualquer das formas legais previstas, dá-se a introdução da norma e a constituição do crédito tributário. Em termos representativos, a capacidade enunciativa deste tipo de lançamento ficaria da seguinte forma:

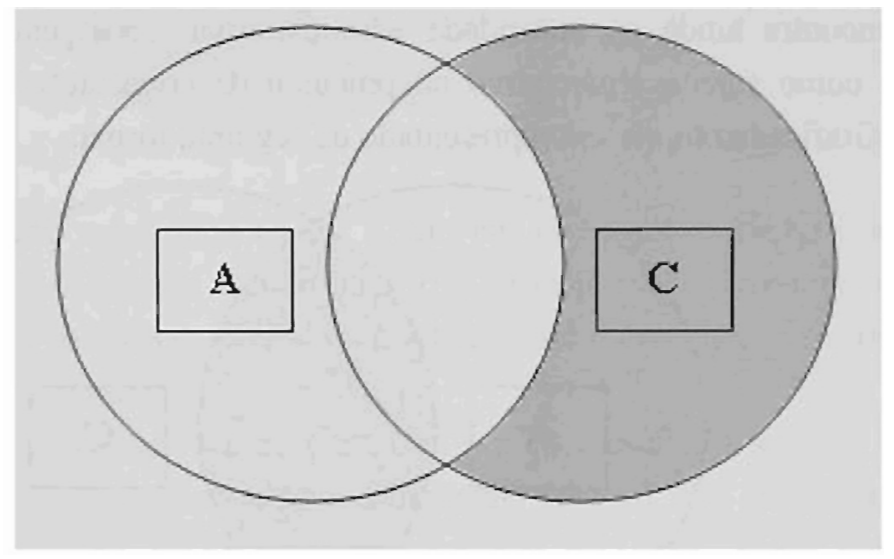

Eis o porquê de encontrarmos nos deveres instrumentais uma figura normativa procedimentalmente peculiar no Direito Administrativo Tributário, na qual, mesmo que produzida por contribuinte, exterioriza a vontade do poder público e, por isso, constitui norma valida no sistema. É ele o responsável pela constituição do fato jurídico, através dos enunciados probatórios que ele próprio produz, assim como também é ele que faz a subsunção deste fato à hipótese da norma geral e abstrata, inserindo no sistema nova norma individual e concreta, agora exacional.

Nos termos do art. 150 do CTN, a atividade enunciativa-normativa, tanto na produção dos deveres instrumentais quanto na antecipação do pagamento, fica sob o controle de legalidade da autoridade administrativa, que se exterioriza no ato de homologação. A homologação, por sua vez, não participa da constituição do fato ou do crédito tributário, mas sim de sua extinção.

Já no Processo Administrativo Federal, cabe ao juiz, autoridade constituinte da norma probatória, apreciar somente as provas juntadas pelas partes nos autos, decidindo e constituindo, a partir deste suporte lingüistico, os fatos e os direitos. A comunicação de determinados indivíduos será produzida e considerada como de direito, recebendo o seu resultado como norma juridica. A pretensão normativa nada mais é que a própria formação da proto-norma-probatória e da proto-norma-exacional, figuras estas 
representativas do objetivo lingüístico-normativo pretendido por aquela parte com o processo. A causa de pedir, na impugnação, ao mesmo tempo que constituirá o protofato, constituirá o antecedente da proto-norma individual e concreta exacional que se requer seja expedida normativamente pela autoridade competente. O pedido formulado na ação, por sua vez, constitui a proposição conseqüente dessa mesma proto-norma. Tanto momento como forma lícita fazem parte das condições de validade do ato probatório em qualquer das situações jurídicas, por mais que no processo administrativo há suavização dessas regras.

O Juiz administrativo, como sujeito enunciador da norma, tem o poderdever de decidir com fulcro à constituição do fato jurídico tributário e a estabilização da lide entre Fisco e contribuinte.

São Paulo, dezembro de 2006. 